Naseri M, Barabady J, Barabadi A. Bioremediation Treatment of Hydrocarbon-Contaminated Arctic Soils: Influencing Parameters. Environmental Science and Pollution Research, 21(19), pp 11250-11265. doi: http://dx.doi.org/10.1007/s11356-014-3122-2

\title{
Bioremediation Treatment of Hydrocarbon-Contaminated Arctic Soils: Influencing Parameters
}

Masoud Naseria ${ }^{*}$, Abbas Barabadia, Javad Barabadya

a Department of Engineering and Safety, UiT the Arctic University of Norway, Troms $\emptyset$, Norway

* Corresponding author; masoud.naseri@uit.no; Tel: +47-77660327; Fax; +47-77680631

\begin{abstract}
The Arctic environment is very vulnerable and sensitive to hydrocarbon pollutants. Soil bioremediation is attracting interest as a promising and cost-effective clean-up and soil decontamination technology in the Arctic regions. However, remoteness, lack of appropriate infrastructure, the harsh climatic conditions in the Arctic and some physical and chemical properties of Arctic soils may reduce the performance and limit the application of this technology.

Therefore, understanding the weaknesses and bottlenecks in the treatment plans, identifying their associated hazards, and providing precautionary measures are essential to improve the overall efficiency and performance of a bioremediation strategy.

The aim of this paper is to review the bioremediation techniques and strategies using microorganisms for treatment of hydrocarbon-contaminated Arctic soils. It takes account of Arctic operational conditions and discusses the factors influencing the performance of a bioremediation treatment plan. Preliminary Hazard Analysis is used as a technique to identify and assess the hazards that threaten the reliability and maintainability of a bioremediation treatment technology. Some key parameters with regard to the feasibility of the suggested preventive/corrective measures are described as well.
\end{abstract}

Keywords: bioremediation; biodegradation; hydrocarbon; Arctic soil; hazard

\section{Introduction}


Arctic soil contamination has various causes, such as well blowouts and accidental oil discharge from tankers, trucks, pipelines, and storage tanks. Discharges from industrial sites, ship repair yards, military bases and fuel tankers also contribute to Arctic environmental pollution (Børresen and Rike 2007; Mohn and Stewart 2000; Evdokimova et al. 2012). The low volatility and water solubility of high molecularweight hydrocarbons makes them persistent in the environment (Speight 2011; Government of Canada 1994), resulting in long-term adverse effects on the environment, the Arctic food chain and human health including: prenatal toxicity; skinrelated diseases; lung cancer; leukaemia; and negative effects on reproduction (Evans et al. 2005; IARC 1989). While low molecular weight aromatics (i.e. one- or two-ring) volatise relatively rapidly, the heavier ones (i.e. polycyclic aromatic hydrocarbon with three and more rings) remain in the environment for quite long times. The natural biodegradation half-lives in soil have been estimated for several PAHs including anthracene (three-ring; 170 days to 8 years), phenanthrene (three-ring; 2.5 days to 5.7 years), and benzo[a]pyrene (five-ring; 8.2 years to 58 years) (Government of Canada 1994).

Due to cost considerations and technological complexities, it is not possible to prevent all the failures which may lead to oil spills. Therefore remediation of oilcontaminated soils is considered to be a passive barrier, used to reduce spill-induced environmental damage.

There are various technologies for soil decontamination that are mainly categorised as physical, chemical, biological, and thermal methods. Biological methods, such as insitu bioremediation, engineered bioremediation systems, bioremediation with fungi, and. In chemical methods hydrocarbon compounds are destroyed, concentrated by the use of one or more types of chemical reactions, such as chemical oxidation and reduction, stabilisation/solidification, electrochemical processes, solvent extraction, and ion exchange. Physical techniques such as soil vapour extraction, vitrification, soil washing, soil heating, and air sparing are based on the differences in physiochemical properties (e.g. viscosity, density, volatility, solubility) of the contaminants and soil, or of the contaminated and uncontaminated soil. Thermal process include physiochemical methods that are employed at elevated temperatures, such as electrical resistance 
heating, steam injection and extraction, and conductive heating (Reddy 2010; Bhandari et al. 2007; EPA 2006; Kulkarni et al. 2012; Lombi and Hamon 2005).

Implementing physical, chemical, and thermal soil remediation techniques in the Arctic is very costly and technologically complex (Vidali 2001). Sometimes they are not even applicable, mainly for reasons of remoteness, harsh climatic conditions and underdeveloped infrastructure. Bioremediation is an alternative soil decontamination technique which basically involves the treatment of hydrocarbon-contaminated soils using hydrocarbon-oxidising microorganisms (Atlas 1981; Fingas 2011). In many cases, compared to other conventional methods, soil bioremediation is proven to be a more promising and cost-effective technique that causes less damage to the environment, has on-site/in-situ applicability and uses minimal technology (Vidali 2001; Speight and Arjoon 2012; Whyte et al. 1999; Liu et al. 2006; Grommen and Verstraete 2002; Bhandari et al. 2007). Several authors have reported the cost of different soil remediation technologies. For instance, Anjum et al. (2012) report that the cost of bioremediation treatment is between US $\$ 50$ and US $\$ 130$ per cubic meter of soil, while incineration and landfill disposal cost US $\$ 300-U S \$ 1,000$ and US $\$ 200-U S \$ 300$ per cubic meter of soil, respectively. Bhandari et al. (2007) also report the estimated cost of some remediation methods for each cubic meter of contaminated soil as US\$13-US\$65 for bioventing, US\$8-US\$1200 for stabilisation/solidification, US\$135-US\$450 for chemical leaching, US\$90-US\$600 for solvent extraction, and US\$75-US\$300 for soil flushing.

In some cases the remediation cost of some physical and chemical methods may be lower than engineered bioremediation techniques. That is because these methods also need their own technology, equipment, and infrastructure that adds to the remediation cost, especially in the remote, less-developed and harsh climate Arctic regions. However, other criteria such as environmental considerations, relocation and disposal of waste, and damage to the site, need also to be considered for selecting a soil remediation method.

There are generally two main bioremediation strategies: biostimulation, and bioaugmentation. The former is basically achieved by adding fertilizers or nutrients to the contaminated site. The latter is defined as the addition of climate-adapted hydrocarbon-degrading microorganisms to the microbial community of the contaminated soil. Both of these strategies are utilized to improve the biodegradation 
rate and process (Whyte et al. 1999), which can be implemented together with some engineered bioremediation techniques. For instance, to implement the biopiling technique, the soil should be piled over an air distribution system. The soil is then aerated and heated to improve the bioremediation treatment performance when soil oxygen level and ambient temperature are limited (Sanscartier et al. 2009).

However, the performance of bioremediation treatment technology is influenced by Arctic operational conditions, such as the harsh climate, lack of visibility, darkness periods and the less developed infrastructure in the Arctic (WWF 2007). The physical and chemical properties of Arctic soils, smaller quantities of available soil microorganisms, freeze-thaw processes in the active permafrost layer, low soil nutrient levels and moisture content also influence bioremediation performance (Atlas 1981; Yang et al. 2009; Colla et al. 2013). Therefore to prepare a highly efficient bioremediation treatment plan, it is of the utmost importance to understand and analyse the Arctic operational conditions and their effects on system performance.

This paper reviews different soil bioremediation techniques and strategies using microorganisms. It further discusses the various parameters that influence the performance of such technologies in Arctic soils. Preliminary hazard analysis is then used to identify and assess the hazards that cause deterioration in the reliability performance of the biodegradation process. Some precautionary and corrective measures are also suggested to mitigate the causes/consequences of such hazards and thus to improve the treatment performance. The key factors that need to be considered for implementing such measures are also described from feasibility viewpoint.

Section 2 presents a review of different bioremediation techniques and strategies. Section 3 discusses the factors that affect the biodegradation process in hydrocarboncontaminated Arctic soils. Section 4 presents the results of a preliminary hazard analysis for the biodegradation process and feasibility of suggested preventive/corrective measures. Sections 5 and 6 respectively present the discussion and conclusions of this study.

\section{Bioremediation of hydrocarbon-contaminated Arctic soils}

The bioremediation technique is basically the treatment of hydrocarboncontaminated soils, using hydrocarbon-oxidising microorganisms (Atlas 1981; Fingas 2011). These microorganisms biodegrade hydrocarbon molecules and transform them 
into simpler ones. They further utilize these molecules as sources of carbon and energy to produce environmentally-harmless end-products, such as carbon dioxide, methane, water, mineral salts and new microbial cellular constituents (U.S. Army Corps of Engineers 1999; Allen 1999). In this regard, biodegradation process is defined as the "chemical breakdown or transformation of a substance caused by organisms or their enzymes", which is the main mechanism in all bioremediation techniques (U.S. Army Corps of Engineers 1999).

\subsection{Bioremediation strategies}

Natural attenuation, which is defined as the degradation of the contaminated soils by a collection of naturally-occurring chemical, biological or physical processes, is known to be very time-consuming in low Arctic temperatures (Kulkarni et al. 2012; Rike et al. 2001). Therefore the chronic adverse effects of hydrocarbon pollutants on the Arctic environment could persist for even more than 20 years (AMAP 1998; Prince et al. 2002; Braddock et al. 2003). Accordingly, other strategies may be implemented to effectively increase both the rate and extent of the biodegradation process. Biostimulation and bioaugmentation are the most common strategies (Whyte et al. 1999). These are discussed in this section.

\subsubsection{Bioaugmentation}

Bioaugmentation is defined as "the addition of microorganisms to enhance a specific biological activity", and is generally applied where the indigenous microorganisms are unable to perform satisfactorily (Vogel 1996). The enhancement of the biodegradation rate is actually achieved by increasing the total number of hydrocarbon-utilizing microorganisms and their concentration in the whole microbial community of soil (Dejonghe et al. 2001). There have been some field studies proving bioaugmentation strategy can result in an increase in bioremediation rate in normal climate conditions and extreme environment (Sood et al. 2010; Colla et al. 2013). However, generally bioaugmentation in the Arctic has not proved to be very effective, especially if the coldadapted indigenous microorganisms already have sufficient potential to degrade the hydrocarbon molecules (Whyte et al. 1999; Margesin 2000; Margesin and Schinner 2001; Margesin 2014). Therefore, bioaugmentation strategy is not covered by this study. 


\subsubsection{Biostimulation}

Biostimulation is defined as adding nutrients to the contaminated soil to improve the overall bioremediation efficiency (Dejonghe et al. 2001). Common nutrients, used in biostimulation, are those rich in phosphorus $(\mathrm{P})$, nitrogen $(\mathrm{N})$, and carbon $(\mathrm{C})$, such as ammonium, urea, and different types of phosphates and nitrates (Allen 1999; Mohn and Stewart 2000). There have been many experimental studies to investigate the effectiveness of the biostimulation strategy in Arctic soils (Børresen and Rike 2007; Braddock and McCarthy 1996; Mohn and Stewart 2000). To arrive at a clear assessment of biostimulation, a variety of other factors such as hydrocarbon bioavailability, type of nutrients, soil properties, temperature, etc. also need to be evaluated simultaneously (Margesin 2000; Mohn and Stewart 2000).

Adsorption of hydrophobic contaminants to soil particles, and their poor water solubility greatly reduce their availability to the hydrocarbon-utilizing microorganisms (i.e. hydrocarbon bioavailability). Therefore, in addition to nutrients, some natural or synthetic surfactants are also added to the contaminated soils to increase the water solubility of hydrocarbons and consequently their mass transfer rate (Franzetti et al. 2008; Van Hamme and Urban 2009; Zoller and Reznik 2006). Synthetic surfactants are petrochemically-driven surface-acting agents, while the biosurfactants (i.e. natural surfactants) are naturally occurring surface-active agents derived from microbial, plant, or animal sources (Finnerty 1994). On the other hand, adding a large amount of surfactants may have some disadvantages such as creating a toxic solution (Zheng and Obbard 2001), or spreading the contamination to the lower layers of soil and even the underground waters by increasing the water solubility of hydrocarbons (Seo et al. 2009).

\subsection{Engineered bioremediation treatment techniques}

Vidali (2001) has categorised bioremediation techniques as: i) in-situ technologies (such as in-situ bioremediation, biosparging, and bioventing), ii) ex-situ methods (e.g. landfarming, composting, biopiles), and iii) bioreactors (for example, slurry reactors and aqueous reactors). In some cases soils cannot be treated in-situ for either regulatory or technical reasons, such as the unavailability of sufficient land, and the risk of underground water or air pollution. Therefore, some ex-situ engineered bioremediation methods need to developed and implemented (Singh et al. 2009), of which the most 
common ones in the Arctic are landfarming, biopiling, and composting (Filler et al. 2001; McCarthy et al. 2004; Antizar-Ladislao et al. 2006; Chemlal et al. 2012).

\subsubsection{Landfarming}

Landfarming is "a simple technique in which contaminated soil is excavated and spread over a prepared bed and periodically tilled until pollutants are degraded" (Vidali 2001). Landfarming is an effective and relatively inexpensive treatment technique for contaminated Arctic soils, particularly where their remoteness requires the use of minimal equipment and technology (Walworth et al. 2008; McCarthy et al. 2004; Paudyn et al. 2008). It may be as simple as spreading soil over a cleared area or it may involve a major construction, with contouring or drainage systems, or both, for the removal of excess water containing dissolved hydrocarbons or nutrients (Walworth et al. 2008). The excavated soil can be amended using water, fertilizers and surfactants. Bulking agents to increase aeration, co-substrates to stimulate microbial metabolism, lime to adjust soil $\mathrm{pH}$ and bacterial inoculations to speed up the remediation process may also be added to the excavated soil. The soil is then tilled periodically to create a more homogenous mixture of nutrients, water, and contaminated soil, as well as promoting aeration (McCarthy et al. 2004; Paudyn et al. 2008; Sanscartier et al. 2009).

\subsubsection{Biopiling}

Thermally enhanced bioremediation schemes, which are the simplest type of biopiling bioremediation technique, are used to increase the microbial activity in the contaminated Arctic soil by increasing soil temperature and extending the period when the Arctic ground is unfrozen (Filler et al. 2008). In more integrated designs soil is amended with nutrients and then piled over a piping system through which air is pumped into the soil. The provision of adequate amounts of oxygen, nutrients and water to hydrocarbon-degrading bacteria in attempts to optimise the bioactivity of microorganisms is another advantage of biopile systems (Chemlal et al. 2012). Couto et al. (2014) carried out a field study in Sisimiut, Greenland, to assess the potential to enhance soil remediation with the surplus heating from an incineration facility. After the first 42 days, the field results showed an enhanced petroleum hydrocarbon removal compared to the natural attenuation. The remediation was even more effective where biostimulation strategy was employed together with active heating. 
The other advantages of implementing biopiles are that they prevent off-site migration of contaminants and nutrient-enriched waters (by situating a leachate collection system), and facilitate the monitoring of the progress of remediation (Filler et al. 2008; Sanscartier et al. 2009; Singh et al. 2009).

However, excess air injection an cause soil drying, which may inhibit microbial activity and accelerate the volatilization of the hydrocarbon contaminants rather than their biodegradation (Sanscartier et al. 2009). Since, in biopile systems, biodegradation is preferred to vaporization, there must be a balance between the injection of heated air, and soil moisture level. For instance, Chemlal et al. (2012) report that during the treatment of some hydrocarbon-contaminated Arctic soils, additional watering was carried out to maintain the soil humidity at between $15-25 \%$ while air was injected.

\subsubsection{Composting}

In composting, contaminated soil is mixed with non-hazardous organic additives such as manure, agricultural or food wastes (which are rich in carbon), organic nitrogen, mineral compounds, and phosphorous required for the growth of microorganisms. As the compost matures, the pollutants are degraded by the active microflora within the mixture (Vidali 2001; Joo et al. 2008). The presence of these organic materials supports the development of a rich microbial population and results in elevated temperature due to the metabolically generated heat (Semple et al. 2001). The main disadvantage is that if this operation is unsuccessful, it will result in a greater quantity of contaminated materials. For instance, periodic addition of organic fertilizers containing fish compost resulted in an increase in toxicity, which was attributed to the formation of toxic metabolites from too rapid a degradation of the fertilizer itself instead of the treated oil (Pelletier et al. 2004). On the other hand there have been successful cases, where the addition of organic wastes to hydrocarbon-contaminated Arctic and Sub-Antarctic soils resulted in an improved biodegradation process (Pelletier et al. 2004; Joo et al. 2008).

\section{Influencing parameters on the bioremediation techniques in the Arctic areas}

To achieve a highly effective bioremediation treatment the first step is to ensure that the biodegradation process is occurring at its maximum rate in the long term. Depending on which type of technique is chosen, some other requirements must be met as well. For instance, one must make sure that the heat injection system in the biopiling 
technique, and tilling and drainage systems in the landfarming method, are functioning as per requirements.

Given the operational conditions, and the pre-defined decontamination requirements (such as the remediation time and final level of hydrocarbon pollutants in the soil), the overall performance of a bioremediation technique can be analysed from the perspective of availability performance. Availability performance is defined as "the ability of an item to be in a state to perform a required function under given conditions at a given instant of time or over a given time interval, assuming that the required external resources are provided" (IEC 60050-191 1990). Therefore, taking the whole bioremediation system as an "item", a set of conditions must be determined under which the treatment strategy is planned and implemented. These conditions include operational conditions (such as the physical and chemical properties of the soil and oil, and climatic conditions), cost, infrastructure, remoteness, and environmental regulations (such as the ecological sensitivity of the contaminated soils, health issues, treatment acceptance criteria and the available waste handling options). Analysis of the availability performance of bioremediation, including elements such as reliability, maintainability, and maintenance support performance (IEC 60050-191 1990) must be carried out in accordance with these conditions.

Reliability performance, defined as "the ability of an item to perform its required function under given conditions for a given time interval" (IEC 60050-191 1990), may need to be improved in order to achieve more effective bioremediation treatment. In this regard, all those parameters that decrease the rate and extent of the biodegradation process influence the reliability performance of the treatment techniques and strategies. If for any reason the reliability of treatment is decreased below the determined level, action must be taken to restore the degradation process to its optimum state. This is described by maintainability performance, which is another element of availability performance, and is defined as "the ability of an item under given conditions of use, to be retained in, or restored to, a state in which it can perform a required function, when maintenance is performed under given conditions and using stated procedures and resources" (IEC 60050-191 1990).

In the case of an engineered bioremediation technique, one can also evaluate the reliability and maintainability performance of all the electrical and mechanical 
equipment, to increase the treatment efficiency. However, since biodegradation is the key mechanism in all bioremediation treatment techniques the focus in this section will be on the factors that influence the biodegradation process in Arctic soils, and thus its reliability performance (Figure 1).

Maintenance support performance is another element of availability performance, defined as "the ability of a maintenance organization, under given conditions, to provide upon demand the resources required to maintain an item, under a given maintenance policy" (IEC 60050-191 1990). Figure 2 depicts a variety of factors that affect the maintenance support performance of an engineered bioremediation treatment. For instance, harsh climatic conditions, limited accessibility to the contaminated site and remoteness are some factors that increase the time required to replace/repair failed components, or essential machinery or mechanical systems.

Attention must be paid to these parameters in the early phases of treatment design. For example, one must ensure that the required power supply is provided if the biopiling treatment method is intended to be implemented. However, for in-situ bioremediation, the only important factor is accessibility to the site if periodic addition of nutrients, bulking agents and other additives are required.

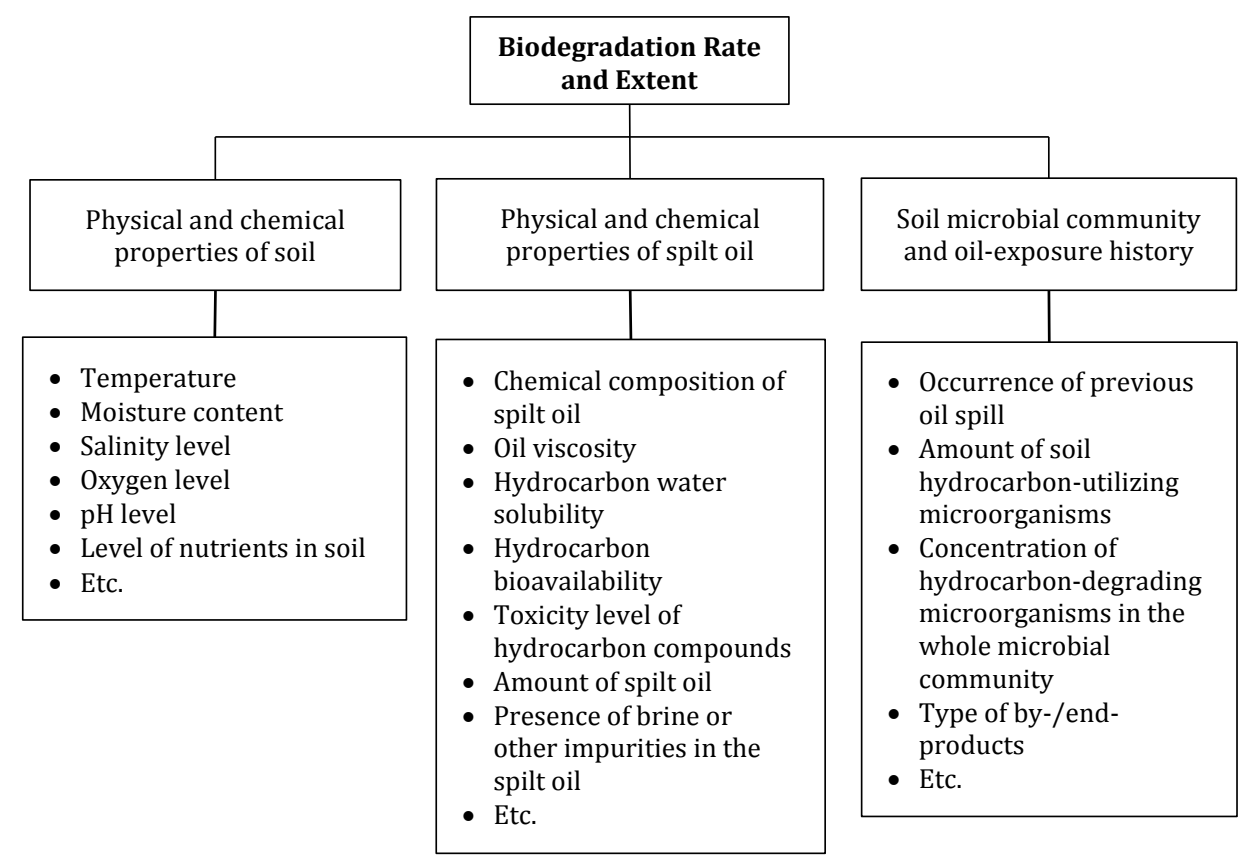

Fig. 1 Influencing factors on the biodegradation process 


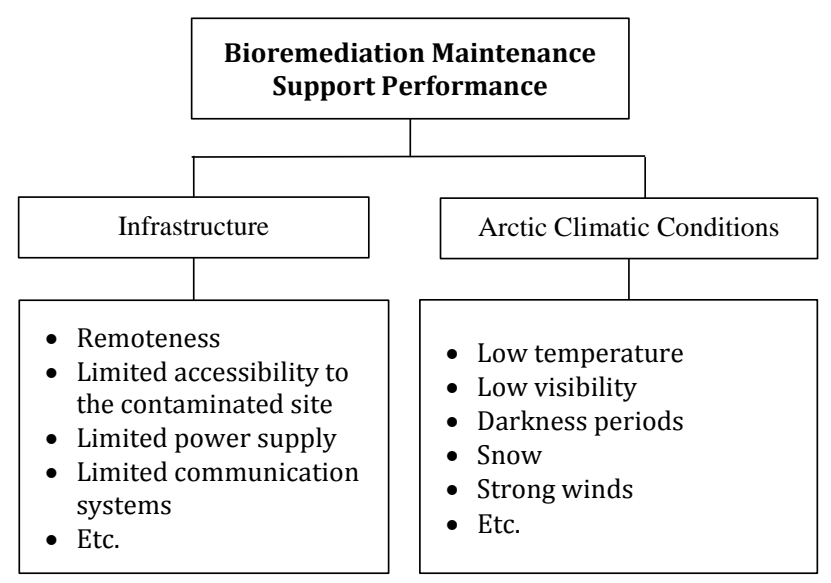

Fig. 2 Factors affecting the maintenance support performance of a bioremediation technique in the Arctic

\subsection{Parameters that influence the biodegradation process in Arctic soils}

\subsubsection{Hydrocarbon type}

Various types of hydrocarbon molecules undergo biodegradation through different oxidation processes. Therefore their biodegradation rates and processes vary, depending upon their molecular structure and constituent components (Fingas 2011; Atlas 1981). Additionally, it has been proved that an identical hydrocarbon compound may have different biodegradation rates, depending upon the other compounds that are present in the hydrocarbon mixture (Atlas 1981).

Generally, while lighter molecules in spilt oil (such as one- and two-ring aromatics) evaporate and degrade rapidly, heavier ones (such as polyaromatic hydrocarbons and asphaltenes) are very resistant to biodegradation and tend to remain in the mixture. This leads to long-term adverse effects on the environment (Atlas 1981; Fingas 2011; Suthersan 1999; Government of Canada 1994). Due to different metabolic routes and pathways microorganisms that are able to biodegrade aliphatic and low molecular weight aromatic hydrocarbons simultaneously are not commonly found. However, if the site has already experienced several hydrocarbon-type contaminations, it is possible to find such microorganisms (Speight and Arjoon 2012). Additionally, implementing some engineered techniques can also facilitate the biodegradation of heavy hydrocarbons. This is of interest in the Arctic, where the ecosystem recovery rate is quite low (Cheremisinoff and Rosenfeld 2009).

With regard to hydrocarbon type, bioremediation techniques have some limitations as well. Several authors have reported relatively successful cases of engineered biodegradation of some tricyclic aromatic compounds such as phenanthrene, 
anthracene, acenaphthene, fluorene (Lors et al. 2012; Lors et al. 2010; Seo et al. 2009). However, the aromatic compounds with more than three rings (e.g. fluoranthene, benz[a]anthracene, benzo[a]pyrene) have extremely low degradation rates and cannot be degraded even after several years (Government of Canada 1994; Mrozik et al. 2003). For instance, based on the comparison of the biodegradation rate of 16 different polyaromatic hydrocarbon compound, Lors et al. (2012) report that relative degradation rates of 3- and 4-ring PAHs were about 32 and 7.2 times greater than those of 5- and 6ring PAHs, respectively. Even though the experiments were done under optimised biodegradation conditions, only $24 \%$ and $22 \%$ of the 5-ring and 6-ring polycyclic hydrocarbons were degraded after 6 month. This raises doubts about the applicability of bioremediation methods in the Arctic regions, where natural attenuation rate is quite slower than in the temperate areas due to several factors such as low temperature. Therefore to clean the site from polyaromatic compounds, alternative methods such as bioremediation with fungi, or remediation using chemical processes need to be taken into account (Bhandari et al. 2007).

\subsubsection{Hydrocarbon bioavailability}

Biodegradation rate is significantly dependent on the availability of the hydrocarbons to the hydrocarbon-utilizing microorganisms (Fingas 2011; Yang et al. 2009; Atlas 1981). Hydrocarbon bioavailability itself depends on several factors like oil viscosity and water solubility, amount of spilt oil, temperature and soil characteristics (Atlas 1981). For example, one of the main reasons that polyaromatic hydrocarbon compounds have low biodegradation rate is due to their low water solubility and also their tendency to bind with soil particles limiting their bioavailability (Mrozik et al. 2003). Since, both oil viscosity and water solubility decrease as temperature drops off (McCain 1990), low Arctic temperatures limit the hydrocarbon bioavailability, and thus hydrocarbon biodegradation. Hydrocarbon bioavailability becomes an even more critical issue during winter, when the soil pore water is frozen, thus inhibiting the transfer of nutrients, oxygen and hydrocarbon molecules.

\subsubsection{Soil temperature}

Low Arctic temperatures influence the rate and extent of biodegradation in a number of ways. Most importantly, temperature affects the metabolic activity of 
hydrocarbon-utilizing microorganisms. Generally the rate of microbial activities increases with temperature, and reaches to its maximum level at an optimum temperature. It declines suddenly with further increase in temperature, and eventually stops after reaching a specific temperature, known as the upper temperature limit. There is also a minimum temperature, below which the rate of metabolic activities tends to zero (Suthersan 1999; Walworth et al. 2001). The temperature range at which metabolic activity can take place and the optimum temperature level at which the metabolic rate is at its maximum, vary depending upon the microorganism type (Atlas 1981). Fingas (2011) states that the most effective hydrocarbon degraders are indigenous ones, which are quite acclimatised to the temperature and other conditions of the treatment site. Psychrophiles (optimum temperature: approximately $15^{\circ} \mathrm{C}$ ), and psychrotrophs (optimum temperature: greater than $15^{\circ} \mathrm{C}$ ) are two types of cold-adapted hydrocarbon-utilizing microorganisms (Margesin 2000), which can grow in the low temperatures experienced in the Arctic. Their growth temperature ranges from $\leq 0^{\circ} \mathrm{C}$ to $\leq 20^{\circ} \mathrm{C}$ and from $0^{\circ} \mathrm{C}$ to $35^{\circ} \mathrm{C}$, respectively (Sainsbury and Singleton 2006).

Generally, during winter the soil temperature is at or below the freezing point. Even in summer time, the soil temperature does not increase to $15^{\circ} \mathrm{C}$ (the optimum temperature level for microbial activity of cold-adapted microorganisms) in some places (Whyte et al. 1999). Therefore the hydrocarbon biodegradation process is generally inhibited, or continues at extremely low rates for most of the year in Arctic soils. To obtain the optimum level of temperature, soil warming technology or heat injection can be provided by implementing engineered biopiles. However, it must be noted that an excess amount of heat contributes to the evaporation of soil pore water, leading to a decrease in hydrocarbon bioavailability. Injecting humidified air seems to be a good solution, as the optimum temperature level can be achieved by injecting heat while enough water is provided to compensate for the evaporated portions.

Evaporation is another mechanism through which low Arctic temperatures influence the biodegradation rate. The evaporation rate of low molecular-weight hydrocarbons drops off with temperature (McCain 1990), and thus their concentration increases in the contaminated soil. This eventually results in slower biodegradation rates because of the increased soil toxicity level due to the toxic nature of low molecularweight hydrocarbons (Atlas 1981; Yang et al. 2009). Additionally, low Arctic 
temperatures increase the oil viscosity and its water solubility (McCain 1990), leading to a decreased hydrocarbon bioavailability and biodegradation rate (Whyte et al. 1998).

\subsubsection{Soil nutrient level}

To survive and continue their microbial activities microorganisms need a number of nutrients, the main ones being carbon, nitrogen, and phosphorous. While carbon is obtained by degradation of hydrocarbon molecules, nitrogen and phosphorous can be found in soil chemicals (Suthersan 1999). However, low Arctic temperatures limit chemical weathering processes and decrease the rate of nutrient recycling in the ecosystem. This eventually results in a deficiency of nitrogen and phosphorous in these environments (Børresen and Rike 2007). When a major oil spill happens, there is a mass of carbon available for microbial growth within a limited area (Margesin and Schinner 2001), while the limited concentrations of nitrogen and phosphorus available in Arctic soils severely limit the extent of hydrocarbon degradation (Atlas 1981).

Therefore the addition of an appropriate quantity of nutrients is a favourable strategy for increasing the metabolic activity of microorganisms and thus the biodegradation rate in cold environments (Walworth et al. 2007; Mohn and Stewart 2000; Couto et al. 2014; Liu et al. 2006). Since concentration and distribution of nutrients is being disturbed by dynamic freeze-thaw processes in active permafrost layers, periodic release of fertilizers is recommended in the long-term, to avoid rapid dissolution and dilution of the added nutrients in the pore water system (Yang et al. 2009).

Several studies indicate the improved biodegradation process resulting from the addition of nutrients in Arctic soils. However, it is also demonstrated that an excessive level of added nutrients decreases the biodegradation rate (Whyte et al. 1999; Børresen and Rike 2007; Mohn and Stewart 2000; Walworth et al. 2007). This reduction is probably due to the increased ionic strength of pore water beyond its optimum level, because most fertilizers are composed of highly water soluble salts like nitrates, phosphates, and ammonium, which quickly dissolve into soil pore water. Hence early evaluation of the soil nutrient level, identification of the optimum level and proportion of different nutrients, and specification of the time-periods when the nutrients need to be added, are key elements of any biostimulation strategy in the Arctic soils. 


\subsubsection{Soil humidity}

Soil humidity can influence the biodegradation rate due to its effects on hydrocarbon bioavailability, diffusion processes, transfer of produced gases, oxygen availability in the soil, and soil toxicity level (Suthersan 1999; Børresen and Rike 2007; Yang et al. 2009). During winter, soil pore water freezes. This leads to a sharp decline in the rate of transfer of hydrocarbon molecules, produced gases, and required nutrients. This consequently results in a decreased biodegradation rate (Johnson et al. 1999; Atlas 1981). Additionally, when pore water freezes, its dissolved salts are expelled to the unfrozen waters, resulting in more concentrated solutions with salinity levels beyond the optimum range. High saline solutions reduce the biodegradation rate due to decreasing water osmotic potential. This process becomes even more problematic if excessive amounts of fertilizers are added during previous summer or autumn, as addition of fertilizers to the soil increases the pore water salinity. (Walworth et al. 2007; Yang et al. 2009).

In the Arctic, during thawing periods in summer, soil humidity increases considerably. This process pushes the oxygen molecules out of the soil porous media. Decreased soil oxygen level results in reduced biodegradation efficiency and rate (Johnson et al. 1999; Yang et al. 2009). Heavy rains, snowmelts, and the thawing process can also spread the dissolved hydrocarbon compounds into the lower layers of soil, where less oxygen is available, thus causing ground-water pollution issues in the longterm. In cases where the soil humidity is low, the appropriate moisture level can be achieved by irrigation, especially if an engineered bioremediation technique is being used.

\subsubsection{Oxygen level}

There are two main metabolism modes for biodegradation of a hydrocarbon molecule, known as aerobic and anaerobic. Of these, the former results in a higher biodegradation rate (Suthersan 1999). Naturally, oxygen is transferred into the lower layers of soil by diffusion. If the physical and chemical properties of contaminated soil inhibit or limit oxygen diffusion, oxygen is consumed at a rate higher than it can be replaced. This results in a process change from aerobic into anaerobic metabolism mode, yielding a lower biodegradation rate (Yang et al. 2009; Atlas 1981). During thawing periods in the Arctic regions, the high amount of water expels the oxygen in the 
soil, decreasing the biodegradation rate. Tilling the soil or adding bulking agents generates an adequate amount of oxygen in the soil, leading to an improved biodegradation process.

\subsubsection{Hydrocarbon saturation in soil (soil toxicity)}

A high concentration of hydrocarbons in the soil reduces the biodegradation rate by creating a toxic environment for microorganisms. For instance, low molecular-weight alkanes and aromatic compounds show acute toxicity, and polyaromatic hydrocarbons cause chronic toxicity for microorganisms (Yang et al. 2009; Atlas 1981; Whyte et al. 1999).

Low Arctic temperatures contribute to increasing soil toxicity levels by reducing the evaporation rate of hydrocarbon compounds, especially the low molecular-weight alkanes and aromatic compounds. Therefore, some precautionary measures need to be taken in an attempt to reduce the hydrocarbon concentration in the contaminated soil and thus improve the biodegradation process. Adsorbing excess amounts of spilt oil using sheet-type sorbents, cutting oily plants and regulating soil temperature are among the methods that may reduce the concentration of oil in the contaminated soil.

\subsubsection{Oil-exposure history of the contaminated soil}

The population of hydrocarbon-utilizing microorganisms and their concentration in the whole microbial community rises rapidly after the occurrence of an oil spill, even in the Arctic ecosystem (Atlas 1981; Whyte et al. 1999; Greenwood et al. 2009). For instance, while in an unpolluted region the proportion of hydrocarbon-degrading bacteria might reach approximately $0.1 \%$ of the bacterial community, it may be as high as $100 \%$ in previously hydrocarbon-polluted soils (Atlas 1981).

Additionally, the community of degrading microorganisms can adapt itself to the previously-spilt hydrocarbons, and then improve the biodegradation process in the case of further spills. As a result, contaminated soils which have previously experienced oilexposure respond relatively faster than sites without any oil-exposure history, where the response time may lag by many weeks or months (Greenwood et al. 2009). Therefore, establishing the oil-exposure history of the contaminated site and evaluating its microbial community plays a crucial role in the selection and success of a bioremediation treatment technique or strategy. This factor is of particular importance for sites where repeated oil discharges have taken place. 


\subsubsection{Soil pH}

Soil $\mathrm{pH}$ variations reduce the biodegradation rate by affecting cell membrane transport and the ability of microorganisms to perform their cellular functions (Suthersan 1999). Production of some organic acids during the biodegradation process (Suthersan 1999) and the alkaline effects of some added nutrients (Børresen and Rike 2007) can alter the soil pH and limit further biodegradation. Therefore controlling soil acidity and its pH level, and keeping it at an optimum level while adding nutrients, is vital. Adding an adequate amount of powdered lime or other conditioners can properly adjust soil pH (Hodges and Simmers 2006).

\subsubsection{Soil salinity}

The biodegradation rate will drop off if soil salinity increases beyond an optimum level (Walworth et al. 2007; Atlas 1981). For instance, attempts at enrichment of microorganisms in waters with salinity of more than $20 \%$ were reported to be unsuccessful (Atlas 1981). There are different reasons for high salinity in a soil, for example discharge of salty waste waters or spillage of oils mixed with brine. In some cases, the contaminated soil already has a high level of salinity (Hodges and Simmers 2006). However, the most common reason for soil salinity increase is the addition of large amounts of fertilizer, mostly composed of highly soluble nitrates or ammonium salts (such as ammonium chloride and ammonium nitrate). These fertilizers change the ionic strength of soil pore water after dissolution (Walworth et al. 2007; Børresen and Rike 2007), leading to a decreased rate and extent of biodegradation. Evaluation of soil salinity level and its nutrients in the early phases, periodic addition of nutrients, and scheduled measurements and monitoring, are among the solutions for keeping the soil salinity level within the optimum range for microbial activities.

\section{Hazard Identification for biodegradation performance}

From the risk assessment perspective, soil bioremediation techniques are passive barriers to oil spills, whose aim is to degrade the hydrocarbon compounds and thus to reduce their adverse environmental effects. As the harsh Arctic climate conditions and the specific characteristics of Arctic soils cause some risks for the remediation techniques and their performance, some risk treatment options need to be developed and implemented. For this purpose, the system-associated risks must be identified, analysed, and then evaluated to determine whether the risk should be modified by risk 
treatment measures in order to satisfy the risk acceptance criteria. Risk management itself includes risk assessment, risk treatment, risk acceptance and risk communication (ISO 2009). Risk assessment is an essential part as it provides the required information for proposing or selecting risk treatment options. To assess the system-associated risk, the first step is to identify a comprehensive list of risks based on those events that might create, enhance, prevent, degrade, accelerate or delay the achievement of objectives (ISO 2009). To achieve this, Hazard Identification (HAZID) techniques can be used, as their objectives (NORSOK 2010) are:

- identifying hazards associated with the defined system(s), and assessing the sources of the hazards, events or sets of circumstances which may cause the hazards and their potential consequences;

- generating a comprehensive list of hazards based on those events and circumstances that might lead to possible unwanted consequences within the scope for the risk assessment process;

- identifying possible risk reducing measures (i.e. preventive/corrective measures, also known as active/passive barriers)

Based on available data, and the nature and objectives of the system and operation, there are various methods of identifying hazards and causes/consequences. Some examples of these methods are the HAZID techniques of safety review, checklist analysis, what-if analysis, relative ranking, preliminary hazard analysis, hazard and operability analysis and failure modes and effects analysis (Mannan 2012; Sutton 2010; Kavianian et al. 1992; Glossop et al. 2000). Preliminary hazard analysis is the technique which is used in this study. It is a qualitative method, which is particularly useful in the early phases of project planning. Causes, major effects, and possible preventive or corrective measures are identified and listed by performing a preliminary hazard analysis (Mannan 2012).

In this study, the hazard assessment has only been carried out for the biodegradation process, which is the main mechanism in all of the bioremediation techniques. However, if it is planned to use an engineered bioremediation technique, then these hazard assessments must be done for the whole treatment system. For instance, if implementation of a biopiling bioremediation is planned, the reliability and 
maintainability performance of all the injection facilities, heat and electricity generators and irrigation and drainage systems must be analysed as well. Accessibility to the site, provision of equipment, and other resources required are among the many factors that need to be considered when analysing the maintenance support performance of systems.

Hazards associated with the biodegradation process are divided into five groups: i) climatic conditions, ii) spilt oil physical and chemical properties, iii) soil characteristics, iv) microorganisms and their metabolic activity, and v) treatment strategy. These hazards were identified and assessed by performing a literature review (Margesin and Schinner 1999; Margesin and Schinner 2001; Filler et al. 2006; Balba et al. 1998; Mrozik et al. 2003; Vidali 2001; Yang et al. 2009; Atlas 1981; Fingas 2011; EPA 2004; Fernández-Luqueño et al. 2011; Wania 1999; Liu et al. 2006) and analysing previous bioremediation treatment case studies in the Arctic regions (Greenwood et al. 2009; Margesin 2000; Masloboev and Evdokimova 2012; Evdokimova et al. 2012; McCarthy et al. 2004; Mohn and Stewart 2000; Sanscartier et al. 2009; Chang and Weaver 1998; Walworth et al. 2001; Walworth et al. 2007; Zytner et al. 2001; Whyte et al. 1999; Paudyn et al. 2008; Børresen and Rike 2007; Filler et al. 2001; Couto et al. 2014). Additionally several meetings were held with different experts in Arctic soil biology, during which various parameters and their effects on hydrocarbon biodegradation processes were discussed. Table 1 presents the hazard assessment log for the category 'climatic conditions'. Hazard analysis for the other categories is presented Appendix 1.

Table 1. HAZID log for biodegradation process (Hazard Category: Climatic Conditions)

\begin{tabular}{|c|c|c|c|c|}
\hline $\begin{array}{l}\text { Hazard } \\
\text { Category }\end{array}$ & $\begin{array}{l}\text { Hazard } \\
\text { Description }\end{array}$ & $\begin{array}{l}\text { Effects on the } \\
\text { System }\end{array}$ & Mechanism & $\begin{array}{l}\text { Preventive/Corrective } \\
\text { Measures }\end{array}$ \\
\hline \multirow{4}{*}{$\begin{array}{l}\text { Climatic } \\
\text { conditions }\end{array}$} & \multirow[t]{4}{*}{$\begin{array}{l}\text { Low } \\
\text { temperature }\end{array}$} & $\begin{array}{l}\text { Reducing } \\
\text { microbial } \\
\text { growth rate }\end{array}$ & $\begin{array}{l}\text { Low soil temperatures may be } \\
\text { beyond the microorganisms' } \\
\text { growth range. }\end{array}$ & \multirow{4}{*}{$\begin{array}{l}\text { Injecting heated air into the soil; } \\
\text { periodic tilling of the soil to } \\
\text { create a more homogenous } \\
\text { temperature profile in the soil }\end{array}$} \\
\hline & & $\begin{array}{l}\text { Increase in soil } \\
\text { toxicity level }\end{array}$ & $\begin{array}{l}\text { Evaporation rate of hydrocarbon } \\
\text { toxic compounds decreases at low } \\
\text { temperatures, and thus soil toxicity } \\
\text { increases. }\end{array}$ & \\
\hline & & \multirow[t]{2}{*}{$\begin{array}{l}\text { Decrease in } \\
\text { hydrocarbon } \\
\text { bioavailability }\end{array}$} & $\begin{array}{l}\text { Oil viscosity increases at low } \\
\text { temperatures, and thus } \\
\text { hydrocarbon bioavailability } \\
\text { decreases. }\end{array}$ & \\
\hline & & & $\begin{array}{l}\text { Solubility of hydrocarbons } \\
\text { decreases with temperature, and } \\
\text { thus hydrocarbon bioavailability } \\
\text { decreases. }\end{array}$ & \\
\hline
\end{tabular}




\begin{tabular}{|l|l|l|l|l|}
\hline \multirow{2}{*}{$\begin{array}{l}\text { Freezing of } \\
\text { soil water }\end{array}$} & $\begin{array}{l}\text { Low oxygen } \\
\text { level of soil }\end{array}$ & $\begin{array}{l}\text { Oxygen diffusion rate decreases } \\
\text { when pore water is frozen. }\end{array}$ & $\begin{array}{l}\text { Injecting heated air into the soil } \\
\text { to provide more oxygen and } \\
\text { heat; injecting hydrogen } \\
\text { peroxide and ozone }\end{array}$ \\
\cline { 2 - 5 } & $\begin{array}{l}\text { Low water } \\
\text { content of soil } \\
\text { snowin; } \\
\text { thawing }\end{array}$ & $\begin{array}{l}\text { Immobile (frozen) water decreases } \\
\text { hydrocarbon bioavailability. } \\
\text { spreading }\end{array}$ & $\begin{array}{l}\text { High soil water content spreads } \\
\text { hydrocarbon to the } \\
\text { uncontaminated lower layers of } \\
\text { soil or underground waters. }\end{array}$ & $\begin{array}{l}\text { Removing snow from the surface } \\
\text { of contaminated soil before thaw } \\
\text { begins in order to reduce the } \\
\text { runoff and infiltration; periodic } \\
\text { tilling of the soil to provide more } \\
\text { oxygen; injecting heated air to } \\
\text { provide oxygen and to vaporize } \\
\text { water; adding bulking agent to } \\
\text { increase aeration; injecting } \\
\text { hydrogen peroxide and ozone }\end{array}$ \\
\cline { 2 - 4 } & $\begin{array}{l}\text { Low oxygen } \\
\text { level of soil } \\
\text { of soil porous media. }\end{array}$ & & \\
\hline
\end{tabular}

As presented in Table 1, for instance, low Arctic temperatures affect the biodegradation process through different mechanisms, most importantly:

- Low soil temperature may be beyond the microorganisms' growth range, resulting in reducing microbial growth rate.

- The evaporation rate of toxic hydrocarbon components (such as low molecularweight compounds) decreases at low temperatures, resulting in a toxic environment for the microorganisms by increasing the soil toxicity level.

- Oil viscosity and water solubility decreases at low temperatures, resulting in less hydrocarbon bioavailability.

To mitigate the adverse effects of low Arctic temperatures, some preventive and corrective measures are also suggested in Table 1. For instance, to mitigate the hazards caused by low Arctic temperatures, installation of soil warming technology (such as heated air injection in the biopiling technique) and periodic soil tilling to create a more homogenous soil temperature profile are suggested measures.

\subsection{Feasibility of suggested preventive/corrective measures}

If the suggested preventive/corrective measures are implemented accordingly, they may improve the soil bioremediation effectiveness. Most of such measures are benefits that may be gained by implementing an engineered bioremediation technique. There must be some criteria based on which decision-makers decide that which technique should be implemented, and what modifications to that technique are required. Figure 3 shows the key elements that must be paid consideration in the design phase in order to 
select a specific bioremediation strategy or technique (i.e. natural attenuation, engineered techniques, biostimulation, bioaugmentation).

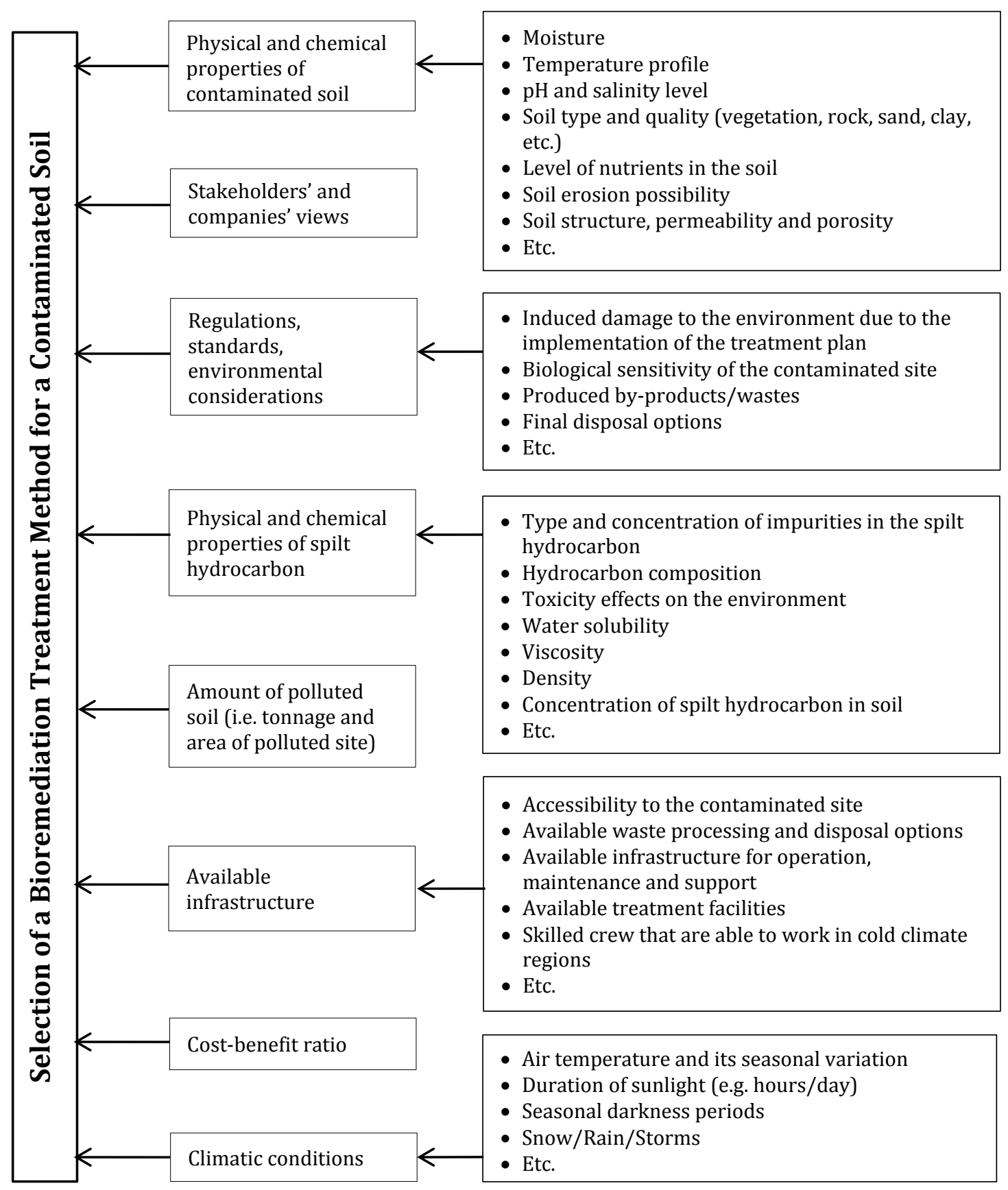

Fig. 3 Key factors that must be taken into account in the decision-making phase for selecting the appropriate soil bioremediation technique and strategy

An early evaluation of the physical and chemical properties of polluted soil and spilt hydrocarbon, community of soil microorganisms, and level of soil nutrient level, play a crucial role in selecting the bioremediation strategy and techniques and its effectiveness (Bhandari et al. 2007; Singh et al. 2005). Selected bioremediation technique must 
comply with the regulations by conserving the land and preventing the spread of pollution. For instance, the bioremediation technique must be able to mitigate the risks posed to human health or other receptors in the environment such as groundwater or surface water, as per in-place regulations. Moreover, the implementation of some methods may not be acceptable due to their negative impacts on soil or surrounding environment (Reddy 2010).

The views of stakeholders and decision-makers form another group of important parameter that influence the selection of bioremediation technique and strategy. Depending on the size and prominence of the site, stakeholders may include for instance land owners, problem holders, site users, site neighbours, insurance authorities, etc. In some cases, the campaigning organisations and local pressure groups may also influence the decision-making process (Reddy 2010). The selected bioremediation method then needs to satisfy the consensus built by all these groups.

Climatic conditions of the polluted site and level of available infrastructure are other factors that must be evaluated thoroughly in the decision-making phase. In addition to their effects on soil properties (e.g. soil temperature and humidity, thaw-freeze periods), climatic conditions may also impact the performance of the engineered systems. For instance, low Arctic temperatures, snow, storms, rain, can cause failures in the mechanical machineries and electrical component, and even adversely affect the performance of the crew. With regard to infrastructure, some factors including: accessibility to the polluted site; available transportation means for equipment, devices, crew, etc.; availability of power generation; providing skilled crew that are able to work in cold climate regions; feasibility of regular monitoring and performing maintenance tasks; must be paid careful attention especially if an engineered system is considered as the bioremediation technique. For instance, if the failure in an oil pipeline causes oil spill in an area where there is no permanent road, electricity, nearby town, etc., establishing the engineered bioremediation techniques may not seem practical and economically beneficial.

The cost-benefit ratio is also a governing factor for selection of bioremediation technique and strategy. The benefits that may be gained from soil bioremediation may include for instance, prevention of the spread of pollution, the land-use of remediated site, and mitigating the health effects. Costs of remediation depend on many factors and 
may be divided into mobilisation, installation, operation (per unit volume/mass of polluted area), demobilisation, monitoring and verification of performance (Reddy 2010; Bhandari et al. 2007). Additionally, one must also consider the tonnage of the polluted site. Clearly, for all soil remediation methods the remediation cost decreases with an increase in the tonnage of the polluted soil. Therefore, even if the infrastructure is available, implementing the engineered bioremediation techniques may not economically beneficial, if the tonnage of polluted soil is significantly small. Other remediation methods may then need to be looked for.

\section{Discussion and conclusions}

In this study, bioremediation of hydrocarbon-contaminated Arctic soils are reviewed. Focusing on natural attenuation of hydrocarbon compounds, several parameters that affect the biodegradation rate and extent are described in details, including: hydrocarbon type and bioavailability; soil temperature; soil nutrient level and its humidity; soil oxygen level; hydrocarbon concentration in soil; soil $\mathrm{pH}$ and salinity; oil exposure history of the contaminated site.

A preliminary hazard analysis is also used to identify and assess system influencing factors, as well as the mechanisms through which they affect the rate and extent of biodegradation. Finally, some preventive and corrective measures are suggested to mitigate such hazards and to avoid situations where the biodegradation process may deteriorate. Most of these measures (e.g. addition of nutrient and surfactants, injection of heated and humidified air) capitalise on the advantages that can be gained by implementing an engineered bioremediation technique, such as biopiling or landfarming. However, implementing these treatment methods may introduce new hazards to the system, the injection of excess heated air being one example. Such hazards are discussed under the category of 'treatment strategy'. Since these parameters have complex effects on the hydrocarbon biodegradation process, any evaluation of one of them must not be carried out in isolation from the other factors.

A feasibility assessment needs to be conducted to decide on which measure or engineered system should be implemented. Some parameters then should be evaluated in more details, such as cost of each method, be benefits that may be gained, level of infrastructure, environmental regulations, goals and objectives of the land owners or problem holders. For example, if an engineered bioremediation technique is selected, 
one must ensure that adequate supplies can be provided upon request in such remote and less-developed Arctic regions. Given the harsh Arctic climatic conditions, reliability and maintainability performance of the mechanical and electrical equipment also need to be evaluated thoroughly.

Moreover, since bioremediation treatment is a site-specific technology, some laboratory experiments, initial field assessments and pilot tests should be conducted to evaluate the biodegradability of hydrocarbon contaminants in a specific soil. The results of such evaluations and studies can be used to optimise the treatment conditions for scaling up the project. Periodic monitoring can also provide information on which further adjustments to the influencing factors may be based. In this phase, it is recommended that further detailed hazard assessments are carried out by a team consisting of managers, specialists, environmentalists, field workers, engineers, , etc. so that none of the many associated hazards are overlooked.

Bioremediation methods have also some limitations. Polycyclic aromatic hydrocarbons, especially the 5- and 6-ring ones, have slow biodegradation rate and then tend to remain in the contaminated soil for quite several years. This is of a matter concern especially in the Arctic regions where biodegradation rate is relatively slower than in the normal climate conditions. Alternative methods then need to looked for and implemented.

\section{References}

Allen MR (1999) Bioremediation of hydrocarbon contaminated Arctic soils. Royal Military College of Canada,

AMAP (1998) AMAP Assessment Report: Arctic pollution issues. Arctic Monitoring and Assessment Program (AMAP), Oslo

Anjum R, Rahman M, Masood F, Malik A (2012) Bioremediation of Pesticides from Soil and Wastewater. In: Environmental Protection Strategies for Sustainable Development. Springer, pp 295-328

Antizar-Ladislao B, Lopez-Real J, Beck AJ (2006) Bioremediation of polycyclic aromatic hydrocarbons (PAH) in an aged coal-tar-contaminated soil using different invessel composting approaches. Journal of Hazardous Materials 137 (3):15831588. doi:http://dx.doi.org/10.1016/i.jhazmat.2006.04.056 
Atlas RM (1981) Microbial degradation of petroleum hydrocarbons: an environmental perspective. Microbiological reviews 45 (1):180-209

Balba M, Al-Awadhi N, Al-Daher R (1998) Bioremediation of oil-contaminated soil: microbiological methods for feasibility assessment and field evaluation. Journal $\begin{array}{llll}\text { of microbiological } & \text { (2):155-164. }\end{array}$ doi:http://dx.doi.org/10.1016/S0167-7012(98)00020-7

Bhandari A, Surampalli RY, Champagne P, Ong SK, Tyagi RD, Lo IMC (2007) Remediation technologies for soils and groundwater. American Society of Civil Engineers, Reston, USA

Braddock JF, Lindstrom JE, Prince RC (2003) Weathering of a subarctic oil spill over 25 years: the Caribou-Poker Creeks Research Watershed experiment. Cold Regions Science and Technology 36 (1-3):11-23. doi:http://dx.doi.org/10.1016/S0165$\underline{232 \times(02) 00076-9}$

Braddock JF, McCarthy KA (1996) Hydrologic and microbiological factors affecting persistence and migration of petroleum hydrocarbons spilled in a continuouspermafrost region. Environmental science \& technology 30 (8):2626-2633

Børresen M, Rike A (2007) Effects of nutrient content, moisture content and salinity on mineralization of hexadecane in an Arctic soil. Cold regions science and technology 48

(2):129-138. doi:http://dx.doi.org/10.1016/j.coldregions.2006.10.006

Chang Z-Z, Weaver RW (1998) Organic bulking agents for enhancing oil bioremediation in soil. Bioremediation Journal 1 (3):173-180

Chemlal R, Tassist A, Drouiche M, Lounici H, Drouiche N, Mameri N (2012) Microbiological aspects study of bioremediation of diesel-contaminated soils by biopile technique. International Biodeterioration \& Biodegradation 75 (0):201206. doi:http://dx.doi.org/10.1016/j.ibiod.2012.09.011

Cheremisinoff NP, Rosenfeld P (2009) Chapter 4 - Exxon Valdez oil spill. In: Cheremisinoff NP, Rosenfeld P (eds) Handbook of Pollution Prevention and Cleaner Production - Best Practices in The Petroleum Industry. William Andrew Publishing, Oxford, pp 113-119. doi:http://dx.doi.org/10.1016/B978-0-8155$\underline{2035-1.10004-1}$ 
Colla TS, Andreazza R, Bücker F, de Souza MM, Tramontini L, Prado GR, Frazzon APG, de Oliveira Camargo FA, Bento FM (2013) Bioremediation assessment of dieselbiodiesel-contaminated soil using an alternative bioaugmentation strategy. Environmental Science and Pollution Research:1-11. doi:http://dx.doi.org/10.1007/s11356-013-2139-2

Couto N, Fritt-Rasmussen J, Jensen PE, Højrup M, Rodrigo AP, Ribeiro AB (2014) Suitability of oil bioremediation in an Artic soil using surplus heating from an incineration facility. Environmental Science and Pollution Research. doi:http://dx.doi.org/10.1007/s11356-013-2466-3

Dejonghe W, Boon N, Seghers D, Top EM, Verstraete W (2001) Bioaugmentation of soils by increasing microbial richness: missing links. Environmental Microbiology 3 (10):649-657. doi:http://dx.doi.org/10.1046/j.1462-2920.2001.00236.x

EPA (2004) How To Evaluate Alternative Cleanup Technologies For Underground Storage Tank Sites: A Guide For Corrective Action Plan Reviewers (EPA 510-R04-002). U.S. Environmental Protection Agency (EPA), Washington, DC

EPA (2006) Engineering Froum Issue Paper - In Situ Treatment Technologies for Contaminated Soil. US Environmental Protection Agency,

Evans MS, Muir D, Lockhart WL, Stern G, Ryan M, Roach P (2005) Persistent organic pollutants and metals in the freshwater biota of the Canadian Subarctic and Arctic: an overview. Science of the total environment 351:94-147

Evdokimova G, Masloboev V, Mozgova N, Myazin V, Fokina N (2012) Bioremediation of Oil-Polluted Cultivated Soils in the Euro-Arctic Region. Journal of Environmental Science and Engineering 1 (9A):1130-1136

Fernández-Luqueño F, Valenzuela-Encinas C, Marsch R, Martínez-Suárez C, VázquezNúñez E, Dendooven L (2011) Microbial communities to mitigate contamination of PAHs in soil-possibilities and challenges: a review. Environmental Science and Pollution Research 18 (1):12-30. doi:http://dx.doi.org/10.1007/s11356$\underline{010-0371-6}$

Filler D, Reynolds C, Snape I, Daugulis A, Barnes D, Williams P (2006) Advances in engineered remediation for use in the Arctic and Antarctica. Polar Record 42 (221):111-120. doi:http://dx.doi.org/10.1017/S003224740500505X 
Filler DM, Barnes DL, Johnson RA, Snape I (2008) Chapter 10 - Thermally enhanced bioremediation and integrated systems. In: Filler DM, Snape I, Barnes DL (eds) Bioremediation of Petroleum Hydrocarbons in Cold Regions. Cambridge University Press, Cambridge,

Filler DM, Lindstrom JE, Braddock JF, Johnson RA, Nickalaski R (2001) Integral biopile components for successful bioremediation in the Arctic. Cold Regions Science and Technology 32 (2):143-156. doi:http://dx.doi.org/10.1016/S0165$\underline{232 X(01) 00020-9}$

Fingas M (2011) Chapter 8 - Introduction to Spill Modeling. In: Mervin F (ed) Oil Spill Science and Technology. Gulf Professional Publishing, Boston, pp 187-200. doi:http://dx.doi.org/10.1016/B978-1-85617-943-0.10008-5

Finnerty WR (1994) Biosurfactants in environmental biotechnology. Current Opinion in Biotechnology 5 (3):291-295. doi:http://dx.doi.org/10.1016/09581669(94)90031-0

Franzetti A, Di Gennaro P, Bestetti G, Lasagni M, Pitea D, Collina E (2008) Selection of surfactants for enhancing diesel hydrocarbons-contaminated media bioremediation. Journal of Hazardous Materials 152 (3):1309-1316

Glossop M, Ioannides A, Gould J (2000) Review of Hazard Identification Techniques. Health and Safety Laboratory, Sheffield

Government of Canada (1994) Polycyclic Aromatic Hydrocarbons. Government of Canada, Environment Canda, Otawa

Greenwood PF, Wibrow S, George SJ, Tibbett M (2009) Hydrocarbon biodegradation and soil microbial community response to repeated oil exposure. Organic Geochemistry 40 (3):293-300. doi:http://dx.doi.org/10.1016/j.orggeochem.2008.12.009

Grommen R, Verstraete W (2002) Environmental biotechnology: the ongoing quest. Journal of Biotechnology 98 (1):113-123. doi:http://dx.doi.org/10.1016/S01681656(02)00090-1

Hodges DA, Simmers RJ (2006) Crude Oil Spills.

IARC (1989) Occupational Exposures in Petroleum Refining; Crude Oil and Major Petroleum Fuels, vol 45. Monographs on the Evaluation of Carcinogenic Risks to Humans. International Agency for Research on Cancer (IARC), 
IEC 60050-191 (1990) International Electrotechnical Vocabulary (IEV)- Chapter 191: Dependability and Quality of Service. International Electrotechnical Commission, Geneva

ISO (2009) ISO 31000: Risk management - Principles and guidelines. ISO, Geneva Johnson TA, Sims GK, Ellsworth TR, Ballance AR (1999) Effects of moisture and sorption on bioavailability of p-hydroxybenzoic acid to Arthrobacter sp. in soil. Microbiological Research 153

(4):349-353. doi:http://dx.doi.org/10.1016/S0944-5013(99)80049-4

Joo HS, Ndegwa PM, Shoda M, Phae CG (2008) Bioremediation of oil-contaminated soil using Candida catenulata and food waste. Environmental Pollution 156 (3):891896. doi:http://dx.doi.org/10.1016/j.envpol.2008.05.026

Kavianian HR, Rao J, Brown G (1992) Application of Hazard Evaluation Techniques to the Design of Potentially Hazardous Industrial Chemical Processes. US Department of Health and Human Services, Public Health Service, Centers for Disease Control, National Institute for Occupatonal Safety and Health, Division of Training and Manpower Development,

Kulkarni S, Palande A, Deshpande M (2012) Bioremediation of Petroleum Hydrocarbons in Soils. In: Satyanarayana T, Johri BN (eds) Microorganisms in Environmental Management. Springer, pp 589-606. doi:http://dx.doi.org/10.1007/978-94-007$\underline{2229-326}$

Liu X, Sun J, Mao G, Dai C, Li C, Zhu Q, Li Y (2006) Advances on bioremediation of oilcontaminated soil in cold region. Chinese Journal of Geochemistry 25:96-97. doi:http://dx.doi.org/10.1007/BF02839923

Lombi E, Hamon RE (2005) Remediation of Polluted Soils. In: Hillel D (ed) Encyclopedia of Soils in the Environment. Elsevier, pp 379-385. doi:http://dx.doi.org/10.1016/B0-12-348530-4/00087-4

Lors C, Damidot D, Ponge J-F, Périé F (2012) Comparison of a bioremediation process of PAHs in a PAH-contaminated soil at field and laboratory scales. Environmental Pollution 165:11-17. doi:http://dx.doi.org/10.1016/j.envpol.2012.02.004

Lors C, Ryngaert A, Périé F, Ludo Diels L, Damidot D (2010) Evolution of bacterial community during bioremediation of PAHs in a coal tar contaminated soil. Chemosphere 81:1263-1271 
Mannan S (2012) Chapter 8 - Hazard Identification. In: Mannan S (ed) Lees' Loss Prevention in the Process Industries (Fourth Edition). Butterworth-Heinemann, Oxford, pp 204-283. doi:http://dx.doi.org/10.1016/B978-0-12-397189-0.00008$\underline{2}$

Margesin R (2000) Potential of cold-adapted microorganisms for bioremediation of oilpolluted Alpine soils. International biodeterioration \& biodegradation 46 (1):310. doi:http://dx.doi.org/10.1016/S0964-8305(00)00049-4

Margesin R (2014) Bioremediation and Biodegradation of Hydrocarbons by ColdAdapted Yeasts. In: Buzzini P, Margesin R (eds) Cold-adapted Yeasts. Springer, pp 465-480. doi:http://dx.doi.org/10.1007/978-3-642-39681-6 21

Margesin R, Schinner F (1999) Biological decontamination of oil spills in cold environments. Journal of Chemical Technology and Biotechnology 74 (5):381389. doi:http://dx.doi.org/10.1002/(SICI)1097-4660(199905)74:5<381::AIDICTB59>3.0.CO;2-0

Margesin R, Schinner F (2001) Biodegradation and bioremediation of hydrocarbons in extreme environments. Applied microbiology and biotechnology 56 (5-6):650663. doi:http://dx.doi.org/10.1007/s002530100701

Masloboev V, Evdokimova G (2012) Bioremediation of oil product contaminated soils in conditions of North Near-Polar Area. Proceedings of the MSTU 15 (2):357-360

McCain WD (1990) The properties of petroleum fluids. PennWell Books, Tulsa

McCarthy K, Walker L, Vigoren L, Bartel J (2004) Remediation of spilled petroleum hydrocarbons by in situ landfarming at an arctic site. Cold regions science and technology 40

(1):31-39. doi:http://dx.doi.org/10.1016/j.coldregions.2004.05.001

Mohn WW, Stewart GR (2000) Limiting factors for hydrocarbon biodegradation at low temperature in Arctic soils. Soil Biology and Biochemistry 32 (8):1161-1172. doi:http://dx.doi.org/10.1016/S0038-0717(00)00032-8

Mrozik A, Piotrowaska-Seget Z, Labuzek S (2003) Bacterial Degradation and Bioremediation of Polycyclic Aromatic Hydrocarbons. Polish Journal of Enviornmental Studies 12 (1):15-25

NORSOK (2010) NORSOK Standard Z-013 - Risk and emergency preparedness assessment. Standards Norway (NORSOK), Lysaker, Norway 
Paudyn K, Rutter A, Kerry Rowe R, Poland JS (2008) Remediation of hydrocarbon contaminated soils in the Canadian Arctic by landfarming. Cold Regions Science $\begin{array}{lll}\text { and } & \text { Technology (1):102-114. }\end{array}$ doi:http://dx.doi.org/10.1016/j.coldregions.2007.07.006

Pelletier E, Delille D, Delille B (2004) Crude oil bioremediation in sub-Antarctic intertidal sediments: chemistry and toxicity of oiled residues. Marine Environmental Research 57

(4):311-327. doi:http://dx.doi.org/10.1016/j.marenvres.2003.07.001

Prince RC, Owens EH, Sergy GA (2002) Weathering of an Arctic oil spill over 20 years: the BIOS experiment revisited. Marine Pollution Bulletin 44 (11):1236-1242. doi:http://dx.doi.org/10.1016/S0025-326X(02)00214-X

Reddy RN (2010) Soil Engineering: Testing, Design, and Remediation. Global Media Delhi

Rike A, Børresen M, Instanes A (2001) Response of cold-adapted microbial populations in a permafrost profile to hydrocarbon contaminants. Polar Record 37 (202):239248. doi:DOI: http://dx.doi.org/10.1017/S0032247400027261

Sainsbury D, Singleton P (2006) Dictionary of microbiology and molecular biology. 3rd Edition Revised edn. John Wiley \& Sons Ltd., Chichester

Sanscartier D, Zeeb B, Koch I, Reimer K (2009) Bioremediation of diesel-contaminated soil by heated and humidified biopile system in cold climates. Cold Regions

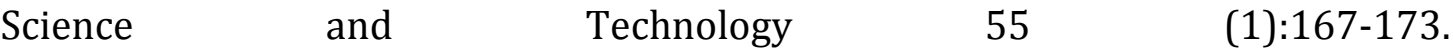
doi:http://dx.doi.org/10.1016/j.coldregions.2008.07.004

Semple KT, Reid BJ, Fermor TR (2001) Impact of composting strategies on the treatment of soils contaminated with organic pollutants. Environmental Pollution 112 (2):269-283. doi:http://dx.doi.org/10.1016/S0269-7491(00)00099-3

Seo Y, Lee W-H, Sorial G, Bishop PL (2009) The application of a mulch biofilm barrier for surfactant enhanced polycyclic aromatic hydrocarbon bioremediation. $\begin{array}{lll}\text { Environmental } & \text { Pollution } & 157 \text { (1):95-101. }\end{array}$ doi:http://dx.doi.org/10.1016/j.envpol.2008.07.022

Singh A, Kuhad RC, Ward OP (2009) Chapter 1 -Biological Remediation of Soil: An Overview of Global Market and Available Technologies. In: Singh A, Kuhad RC, 
Ward OP (eds) Advances in Applied Bioremediation. vol 17. Springer. doi:http://dx.doi.org/10.1007/978-3-540-89621-0 1

Singh A, Ward OP, Kuhad RC (2005) Feasibility Studies for Microbial Remediation Hydrocarbon-Contaminated Soil. In: Margesin R, Schinner F (eds) Manual for Soil Analysis - Monitoring and Assessing Soil Bioremediation. Springer,

Sood N, Patle S, Lal B (2010) Bioremediation of acidic oily sludge-contaminated soil by the novel yeast strain Candida digboiensis TERI ASN6. Environmental Science and Pollution Research 17 (3):603-610. doi:http://dx.doi.org/10.1007/s11356$\underline{009-0239-9}$

Speight JG (2011) Handbook of industrial hydrocarbon processes. Elsevier. doi:http://dx.doi.org/10.1016/B978-0-7506-8632-7.10020-9

Speight JG, Arjoon KK (2012) Bioremediation of Petroleum and Petroleum Products. John Wiley \& Sons,

Suthersan S (1999) In situ bioremediation. Remediation engineering: desing concepts Ed Suthan S Suthersan Boca Raton: CRC: Press LLC

Sutton I (2010) Chapter 3 - Hazards identification. In: Sutton I (ed) Process Risk and Reliability Management. William Andrew Publishing, Oxford, pp 79-190. doi:http://dx.doi.org/10.1016/B978-1-4377-7805-2.10003-1

U.S. Army Corps of Engineers (1999) Engineering and Design - Lubricants and Hydraulic Fluids - Manual EM 1110-2-1424. U.S. Army Corps of Engineers, Washington DC

Van Hamme JD, Urban J (2009) Biosurfactants in Bioremediation. In: Singh A, Kuhad RC, Ward OP (eds) Advances in Applied Bioremediation. Springer, pp 73-89

Vidali M (2001) Bioremediation. An overview. Pure and Applied Chemistry 73 (7):11631172

Vogel TM (1996) Bioaugmentation as a soil bioremediation approach. Current opinion in biotechnology 7 (3):311-316

Walworth J, Braddock J, Woolard C (2001) Nutrient and temperature interactions in bioremediation of cryic soils. Cold Regions Science and Technology 32 (2-3):8591. doi:http://dx.doi.org/10.1016/S0165-232X(00)00020-3

Walworth J, Pond A, Snape I, Rayner J, Ferguson S, Harvey P (2007) Nitrogen requirements for maximizing petroleum bioremediation in a sub-Antarctic soil. 
$\begin{array}{llll}\text { Cold Regions } & \text { Science and } & \text { (2):84-91. }\end{array}$ doi:http://dx.doi.org/10.1016/j.coldregions.2006.07.001

Walworth JL, Reynolds CM, Rutter A, Snape I (2008) Chapter 9 - Landfarming. In: Filler DM, Snape I, Barnes DL (eds) Bioremediation of Petroleum Hydrocarbons in Cold Regions. Cambridge University Press, Cambridge,

Wania F (1999) On the origin of elevated levels of persistent chemicals in the environment. Environmental Science and Pollution Research 6 (1):11-19

Whyte LG, Bourbonnière L, Bellerose C, Greer CW (1999) Bioremediation assessment of hydrocarbon-contaminated soils from the high Arctic. Biomeridiation Journal 3 (1):69-80. doi:http://dx.doi.org/10.1080/10889869991219217

Whyte LG, Hawari J, Zhou E, Bourbonnière L, Inniss WE, Greer CW (1998) Biodegradation of Variable-Chain-Length Alkanes at Low Temperatures by a Psychrotrophic Rhodococcussp. Applied and environmental microbiology 64 (7):2578-2584

WWF (2007) Oil spill responce challenges in the Arctic. WWF International Arctic Programme, Oslo

Yang S-Z, Jin H-J, Wei Z, He R-X, Ji Y-J, Li X-M, Yu S-P (2009) Bioremediation of oil spills in cold environments: A review. Pedosphere 19 (3):371-381

Zheng Z, Obbard JP (2001) Effect of non-ionic surfactants on elimination of polycyclic aromatic hydrocarbons (PAHs) in soil-slurry by Phanerochaete chrysosporium. Journal of Chemical Technology and Biotechnology 76 (4):423-429. doi:http://dx.doi.org/10.1002/jctb.396

Zoller U, Reznik A (2006) In-situ surfactant/surfactant-nutrient mix-enhanced bioremediation of NAPL (fuel)-contaminated sandy soil aquifers. Environmental Science and Pollution Research 13 (6):392-397

Zytner R, Salb A, Brook T, Leunissen M, Stiver W (2001) Bioremediation of diesel fuel contaminated soil. Canadian Journal of Civil Engineering 28 (S1):131-140

\section{Appendix A}

Complete list of hazards, divided in five categories as well as their effects on the system and the mechanisms through which those effects are expected are presented in Table A1. The rightmost column suggests a number of preventive/corrective measures, by which the corresponding hazards can be tackled and mitigated accordingly. 
Table A1. Preliminary hazard analysis for the biodegradation process in contaminated Arctic soils

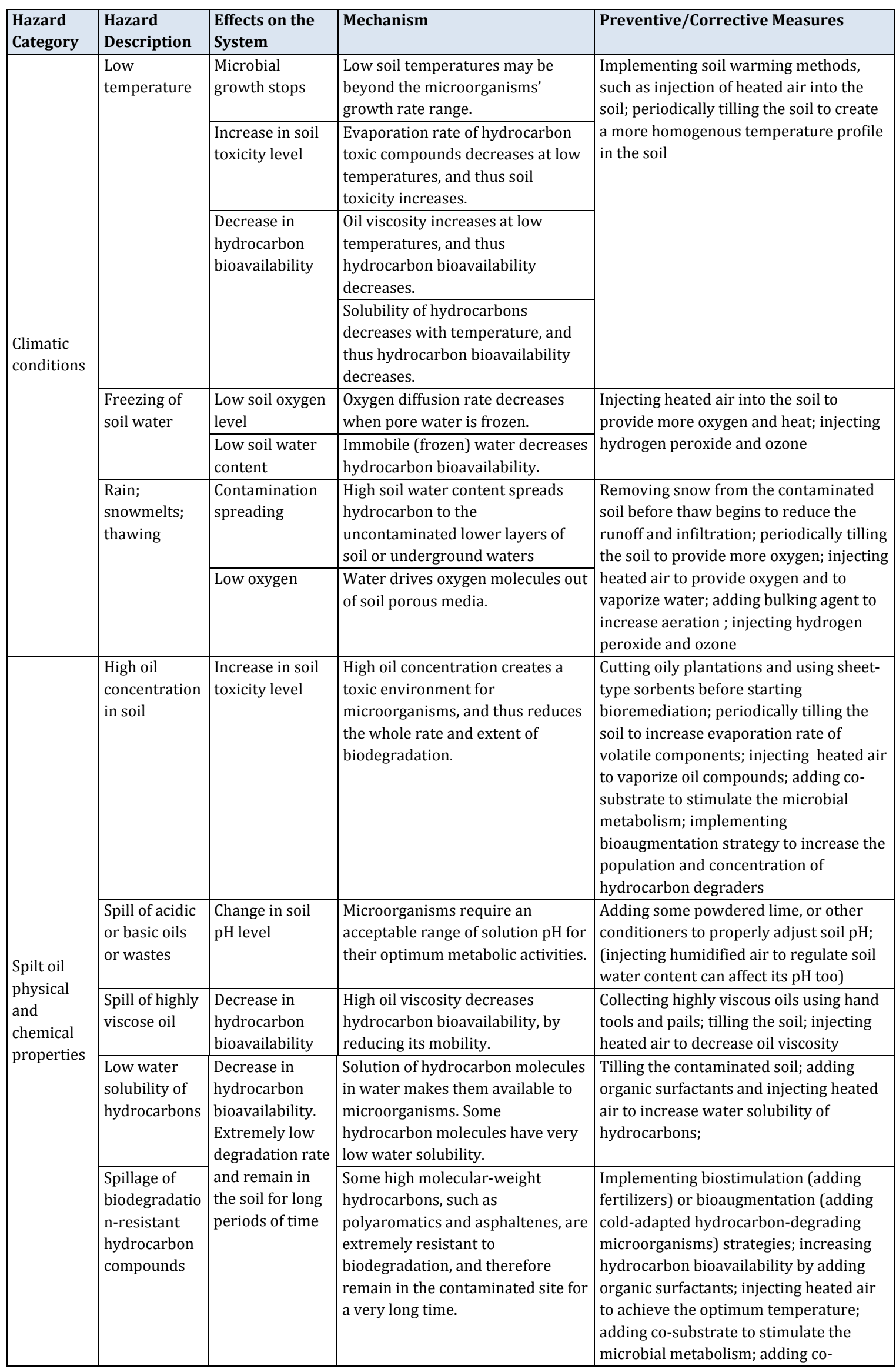




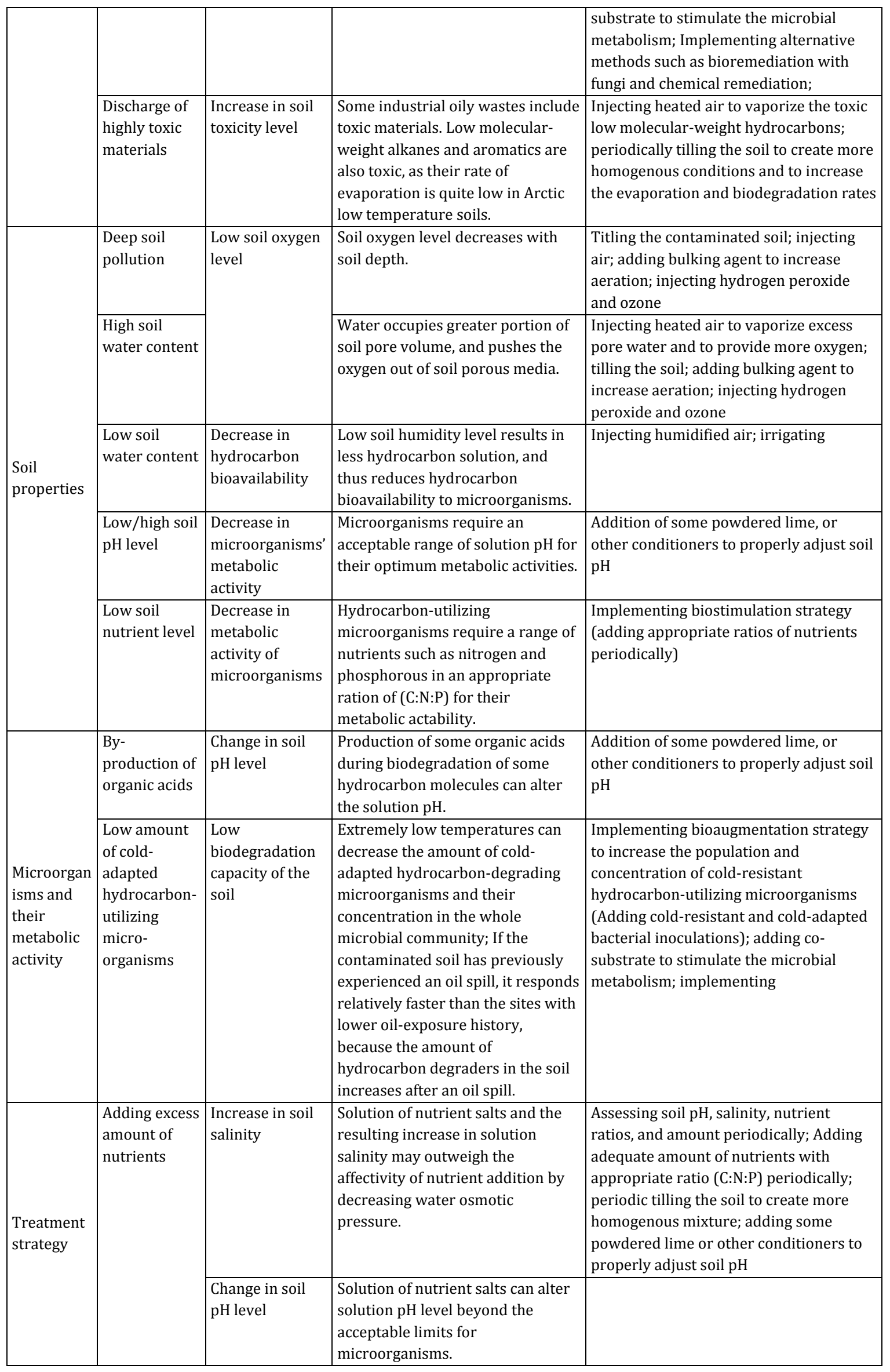




\begin{tabular}{|l|l|l|l|l|}
\hline & $\begin{array}{l}\text { Providing } \\
\text { excess soil } \\
\text { water content }\end{array}$ & $\begin{array}{l}\text { Spreading } \\
\text { contamination } \\
\text { to the } \\
\text { uncontaminated } \\
\text { soils, and } \\
\text { underground } \\
\text { water }\end{array}$ & $\begin{array}{l}\text { lurfactants increase the water } \\
\text { solubility of hydrocarbons. } \\
\text { Addition of a large amount of } \\
\text { surfactant, in the presence of high } \\
\text { water content, spreads the } \\
\text { contamination to the lower layers } \\
\text { of the soil. }\end{array}$ & $\begin{array}{l}\text { Assessing soil humidity periodically; } \\
\text { regulating temperature (injecting heated } \\
\text { air) to vaporize excess pore water; } \\
\text { periodically tilling the soil to vaporize } \\
\text { water and create a homogenous mixture } \\
\text { surfactants }\end{array}$ \\
\cline { 2 - 5 } $\begin{array}{l}\text { Providing } \\
\text { excess heat } \\
\text { (high } \\
\text { temperature) }\end{array}$ & $\begin{array}{l}\text { Low soil water } \\
\text { content }\end{array}$ & $\begin{array}{l}\text { Injecting heated air may vaporize } \\
\text { most of the pore water and thus } \\
\text { decrease the hydrocarbon } \\
\text { bioavailability. }\end{array}$ & $\begin{array}{l}\text { Injecting humidified heated air; } \\
\text { irrigating; }\end{array}$ \\
\cline { 2 - 5 } & $\begin{array}{l}\text { Decrease in } \\
\text { microbial } \\
\text { growth rate }\end{array}$ & $\begin{array}{l}\text { Although microbial growth rate } \\
\text { increases with temperature, there } \\
\text { is an optimum temperature, at } \\
\text { which the growth rate becomes } \\
\text { maximal, as well as a maximum } \\
\text { temperature, at which microbial } \\
\text { growth almost stops }\end{array}$ & $\begin{array}{l}\text { Determining the optimum, minimum, and } \\
\text { maximum temperatures for growth, and } \\
\text { periodically regulating the temperature, } \\
\text { with regard to this temperature range }\end{array}$ \\
\hline
\end{tabular}

